\title{
Generational differences in policy preferences for water sharing: implications for the future
}

\author{
H. Bjornlund ${ }^{1,2}$, W. Xu ${ }^{1} \&$ X. Zhao ${ }^{1}$ \\ ${ }^{1}$ University of Lethbridge, Canada \\ ${ }^{2}$ University of South Australia, Australia
}

\begin{abstract}
Conflicts over reallocation of water, from existing water licence holders to meet new demand from consumptive users and the environment, are likely to intensify over time. This study explores the support for three policy orientations towards water sharing among four generations of voters. We find that the four generations have significantly different level of support for policies aiming at protecting the environment and protecting current licence holders. Younger generations are more supportive of both. This could suggest two future policy scenarios. Conflicts could intensify as greater support is likely to emerge from those two presumably opposing policy orientation as the current voting base ages, or the increased support for both orientations could result in a higher willingness for policy compromises.
\end{abstract}

Keywords: sustainable irrigation, water sharing, Alberta, Canada.

\section{Introduction}

Many regions of the world are running out of water as existing water resources are being over-extracted leading to a decline in water quality and deterioration of riverine ecosystems. As a result, economic as well as human use of water is threatened and continued prosperity and quality of life are uncertain. In response to such challenges, river basins are being closed and no new applications for licensed allocations are being accepted. Water bodies are increasingly being used for recreational purposes contributing to a change in society's values towards water and increasing the demand for improving water quality and riverine environments. This can only be achieved by reducing extractive use of water. Therefore, the pressure on water resources is from both economic and population 
growth and public demand for reducing water extraction to improve environmental outcome.

There is therefore a need to find ways of sharing water allocated to extractive uses, and to reduce the current level of extraction, that are acceptable to the affected key stakeholders. Given that irrigation accounts for up to $80 \%$ of water use, this sector needs to play a critical role in these processes. In countries where water sharing has been implemented, they have often been met with widespread opposition. Stakeholder groups are concerned for different reasons. For irrigators, water is the foundation under the productivity and value of their farm. For rural communities, reducing water for irrigation could result in a loss of economic activity, jobs and services leading to a decline or change in population and threaten the viability of communities. For environmental groups, water sharing might activate previously unused water and further decrease in-stream flows. For taxpayers, if reduction in water extraction is achieved through government buy back, they could argue that existing licence holders are simply custodians of the water as it belongs to society and should be used in the most beneficial way for that society at any given time.

Given the importance of achieving water sharing, it is critical to understand the reasons for the opposition to and support for various water sharing policies. How does such support/opposition vary across space and community groups and what factors influence it? A number of studies have investigated these issues in the context of Southern Alberta [1,2]. The opposition to such policies could be caused by the attitudes and beliefs of the existing generation of voters. These could change over time as younger people are more environmentally aware. This paper explores generational differences in people's policy preferences for water sharing in order to shed some light on future changes in the voting public.

\section{The Alberta context}

Water availability and the demand for water vary across Alberta. The northern part is water rich, sparsely populated and has limited economic activity apart from the mining sector. Supply is therefore ample and there is limited competition for water. The issue is water quality, mainly due to intensive mining activities, especially in the oil sands [3]. In the southern part, water is scarce and as a result of population pressure and economic growth competition for water is tense and water scarcity is therefore emerging, especially within the South Saskatchewan River Basin (SSRB), the home for some $65 \%$ of all irrigation in Canada. Hence, it is here policies to manage scarcity and share limited resources started to emerge in the early 1990s.

\subsection{Early management and policy responses to scarcity in Alberta}

The first measure to manage the strain on water resources in the SSRB was taken in 1991 when the Alberta Government introduced guidelines for capping the amount of water allocated to irrigation. In response to severe drought in 2001/02, a moratorium was placed on the issuing of new licensed allocations within the 
southern tributaries of the Oldman River in the southern SSRB [4] and a process of public consultation to develop a new water management strategy was initiated, which resulted in the 2003 Water for Life strategy [5]. It acknowledges that water within the SSRB is fully or overcommitted, demand is likely to increase due to estimated future population and economic growth, and there is an increased demand for in-stream flows.

As a result of these developments and new legislations, Water Planning and Advisory Councils (WPAC) were formed within Alberta's Basins tasked with developing water management plans. The first Draft Water Management Plan for the SSRB was released in 2005 [6]. This plan concluded that the SSRB was fully or over-allocated and many river reaches were degraded or suffered from negative environmental impacts as a result of current levels of water diversion.

In response to this plan, the government decided to close the SSRB so that no new applications would be accepted for licensed water allocations, except for the Red Dear River [6]. The plan also identified the factors which will increase the pressure on water resources in the future: i) the non-irrigation sector could increase its demand by $35-67 \%$ by 2021 and by $52-136 \%$ by 2046 ; ii) irrigation could expand its extraction by $10 \%$ to $20 \%$ and, iii) the population could increase from 1.3 million in 1996 to more than two million by 2021 and exceed three million by 2046 . Climate change predictions suggest that the region is likely to face a change in the pattern and type of precipitation, further increasing pressures on water resources [7].

While water is over-allocated and negative environmental impacts of the current level of extraction have been identified; the full impact has not yet materialized, because licence holders only use about $60 \%$ of their allocated water. Part of the concern that environmental NGOs has expressed about water sharing is associated with the fear that it would activate unused water and that improving irrigation efficiency could increase net use of water, increasing environmental stress within the rivers. Also in the Alberta context, the role of irrigation in achieving water sharing cannot be overestimated as it controls $87 \%$ of all licensed water allocations and it represents most of the senior licences [8]. Hence, irrigation users control by far the biggest source of water to meet new demands.

\subsection{Water legislation}

Canada inherited the riparian doctrine of water allocation when it came under British control. This doctrine also applied within the area controlled by the Hudson Bay Company which later became the Northwest Territories from which Alberta was carved in 1905. As in Australia, this doctrine soon became an impediment to development and settlement of the water scarce interior regions. In 1898, that doctrine was largely abandoned with the Northwest Irrigation Act, largely modelled on the Victorian Water Act of 1886. Ownership of water was vested in the crown and licences were issued to individuals who wanted to extract water. These licences were issued under the prior allocation system under which each licence has a priority date which is the date it was granted. During periods when supply is restricted, senior licence holders are satisfied in full 
before junior licence holders get access to water; consequently, some junior licensees might not get any water at all. This system has been retained through a series of Water Acts, most recently in the Water Act, 1999. It has been argued that this might not continue to be the most beneficial way of allocating Alberta's water [9-11]. In 2009, the Minister commenced a process of developing a new water allocation and management framework [10]. However, nothing has since happened and a new consultation process is currently under way.

Water sharing can take place in a number of ways. As part of the development of the Water Management Plans, the WPAC has to define water conservation objectives. Upon approval of these plans, the Minister issues a licence to secure these objectives. However their priority is of the date the plan is approved; hence they are the most junior licences hence unlikely to receive any water during periods of severe stress.

Water trading was introduced by the Water Act (1999) but can only take place subject to an approved water management plan and the approval of the Director, under the Administrative Guidelines for Transferring Water Allocations [4]. Under the Act, licence holders can share their water in a number of ways. They can: i) buy, sell, or lease their licensed allocations, or ii) assign the right to extract water under their licence to another licence holder during a given season. However, assignments cannot be made to a water user who does not already hold a licence and can therefore not be used to assist the establishment of new water users.

District irrigators do not have their own individual licences and hence cannot trade under the Water Act. Instead, they have access to a share of the district's licences according to the number of acres they have registered on the districts assessment roll. These irrigators' ability to trade water is set out in the Irrigation Districts Act, 2000 (IDA). Trade between irrigators within the same district is relatively unrestricted while trading with an entity outside their district needs the approval of a majority of all irrigators within their district via a plebiscite.

The IDA provides districts with an alternative way of sharing their water to meet outside needs. They can enter into a water supply agreement under which they enter into a contract to deliver a volume of water for a period of time. This is only possible under the condition of the district's licence which defines how much water under a licence can be used for non-irrigation purposes.

Under the Water Act, 1999 water licences can only be issued for extractive purposes. Consequently, private individual or environmental organizations cannot purchase water allocations and leave the water in the river for environmental or recreational purposes, as has occurred in Australia and the US [12-14].

\subsection{Water sharing options}

Water sharing between existing and new users including the environment can be implemented in two ways: i) governments can administratively reallocate or reduce licensed allocation with or without compensation; ii) water markets can be used to reallocate water through voluntary transactions between buyers and 
sellers. Under this system government can buy back licensed water allocations from existing users and leave the water in the river for the environment.

Administrative water sharing is relatively uncommon as the political will to implement it is absent due to the potentially high political cost and need for legislative changes. Hence, governments and international institutions have increasingly promoted market based approaches to achieve these water sharing outcomes and to minimize the socio-economic consequences.

As discussed, concern over water sharing has centred on the socioeconomic impact on irrigators and their communities as it is feared that sharing water will threaten the viability of irrigation communities [15]. These concerns put an end to the process of administrative reductions in extraction rights in Australia in 2006 [16]. However, in Australia it has proven difficult to isolate the impacts of water sharing from the structural adjustment pressures that rural communities have encountered in the past several decades [17].

The magnitude of such impacts depends on how water sharing strategies are implemented and how the irrigators respond to them. They may improve their irrigation efficiency, change to crops that need less water for the same yield, or shift to crops that produce a higher financial return per unit of water used. If so, the value of production may remain relatively stable and thereby minimize the perceived negative impacts. If reductions in extraction are achieved by government buy-back, sellers could use the proceed to finance an alternative way of living, reduce debt, invest in more efficient irrigation technology, or change to more water efficient crops. If more productive or efficient irrigators buy licensed allocations from unproductive or inefficient irrigators, overall production may increase.

If the policy objective is to increase in-stream flows, then improving irrigation efficiency may be counter-productive in jurisdictions such as Alberta, where irrigators have the consumptive right to their allocated water. In such circumstance, improving irrigation efficiency might reduce in-stream flows as most of the water 'lost' in fact return to the rivers either as runoff or via groundwater. Only the water lost to evaporation or seepage into very deep or saline aquifers represents true water savings. This issue has caused significant debate and concern in Australia with its focus on upgrading irrigation infrastructure [18].

This raises four questions for water sharing: i) Should it be compulsory for water right holders to adopt water saving practices and share water? ii) Should such actions be subsidized by taxpayers, or funded by resource users? iii) What should the relative roles of government and markets be in water sharing? and iv) What should happen to the water saved? In this paper we investigate how the preferences for policies addressing these questions vary across generation within the SSRB, Alberta.

\section{The influence of age: the literature}

A number of studies have investigated what influences people's values and attitudes toward the environment, their environmental behaviour and their policy 
preferences. Many of these have included age as one of the parameters. Hines et al. [19] conducted a meta-analysis of ten studies into the relationship between environmental behaviour and age. They found that younger people were slightly more likely to engage in environmentally responsible behaviour and concluded that the age-environmental behaviour relationship was tenuous.

Dunlap and Heffernan [20] conducted one of the first studies focusing on the relationship between age and participation in outdoor leisure activities and environmental concern. They found the relationship to be non-spurious. Geisler et al. [21] expanded this work and found that age consistently was the most influential predictor of awareness of environmental problems. Buttel [22] explored the relationship between education, age and environmental concern and support for environmental reform and found age more strongly correlated than education. A number of studies have found that younger people has a higher level of environmental concern (e.g. [23-25]).

Whittaker et al. [26] undertook a study of factors predicting peoples intend to conserve water by installing a dual-flush toilet during two periods. During the first period, age was significant but only when other predictors were ignored and during the second period, age was insignificant. Chapman [25] found that older people (45-64) were most likely to undertake actions to reduce their personal electricity and water use and to participate in recycling.

A study by Bjornlund et al. [1] into the factors influencing policy preference for water sharing found that age had a positive influence on the support for policies granting strong powers over water allocation to the government while it had a negative effect on the support for policies aiming at protecting the environment.

The study by Honnold [27] is of particular interest to this study. He made a longitudinal study of seven age groups to follow how people's environmental concern changes as they mature. He found that the level of environmental concern declined in all age groups over the period from 1973 to 1980. However, including 'period effects' in a regression analysis, he found that the decreased level of environmental concern was more influenced by an increasing conservative political climate over that period than the aging process of the respondents. If people change their policy preferences as they age, then investigating the current generations' policy preferences as indicators of future changes within the voting population makes little sense. However, if the current generations will largely retain their policy preferences as they age, and if the next generation of voters are most likely to reflect the preference of the currently youngest generation of voters, then knowledge about the policy preferences for water sharing of current generations will provide insight into how the overall policy preferences of society will change in the future.

\section{Data sources and methodology}

This paper is based on three surveys of residents in the SSRB with different levels of resource dependence, varying experience with water restrictions and different levels of exposure to environmental degradation under the current level 
of water diversion. The first survey was carried out in the southern part of the basin. This is the most intensely irrigated part of the basin and most exposed to water restrictions as well as environmental degradation. During the fall of 2009, 3000 questionnaires were sent to residents in Lethbridge; a city with a population of about 95,000 people. While it has a diverse economy with major educational and research institutions, it retains strong links to, and dependence on, the irrigation sector. Another 3,000 questionnaires were mailed to residents in four small irrigation communities outside Lethbridge: Raymond, Taber, Magrath and Sterling (RTMS), totally dependent on irrigation as the economic driver of jobs and demand for services.

The second survey was carried out in the northern part of the basin. This area is less intensely irrigated, has never experienced water restriction and has little exposure to environmental degradation due to the current level of water extraction. During the fall of 2010, 3000 questionnaires were mailed to residents in Calgary, the commercial centre of Alberta with little dependence on water use for its economic wellbeing, while its citizens' lifestyles would benefit from rural-urban/environment transfers. In addition, 2,700 questionnaires were sent to residents in Strathmore $50 \mathrm{~km}$ east of Calgary. It is the administrative centre for the Western Irrigation District and houses many service industries dependent on irrigation. However, it has other economic activities and job opportunities due to its proximity to Calgary.

A total of 671 useable responses were collected in Lethbridge, 499 in RTMS, 476 in Calgary and 347 in Strathmore. The effective response rates were 21\% for the first survey and $17 \%$ for the second. Given these were household surveys; the respondents are not representative of the population with respect to age and gender. To better facilitate an analysis of the influence of age and identify generational differences in policy preferences, an online survey was conducted in the fall of 2012 targeted at young adult between 18 and 35 . Invitations were sent to students at the universities, colleges as well as a number of sports and youth organizations, a total of 605 responses were received. In all, 2,598 questionnaires were obtained from the three surveys, of which 133 did not provide their age, resulting in 2,465 useable responses.

The respondents were asked to rate their level of agreement with ten policy statements reflecting the water sharing policy options discussed above, as well as a range of questions related to socio-demographic characteristics. To facilitate the analysis of generational differences, respondents were grouped into four generations: i) youth: 18-29; ii) middle aged: 30-49; iii) older: 50-69; and iv) senior: aged $70+$. Factor analyses were applied to the policy statements to generate policy orientations. ANOVA tests were used to identify differences in factor scores between any two generations. Finally, regression analyses were used to identify causal relationships between generations and policy preferences. 


\section{Exploring generational differences in water sharing preferences}

Factor analysis identified three policy orientations (Table 1). Factor one includes three policy statements. It represents policies granting relative strong powers to the government in water allocation issues and is labelled 'Strong Government'. Factor two includes five policy statements reflecting policies aiming at securing

Table 1: $\quad$ Factor analysis on ten policy statements.

\begin{tabular}{|c|c|c|c|c|}
\hline Policy statement/factor number & 1 & 2 & 3 & $\operatorname{Mean}^{1}$ \\
\hline $\begin{array}{l}\text { If water is to be traded among irrigation } \\
\text { districts and/or municipalities, the } \\
\text { government should set the price. }\end{array}$ & .81 & & & $\begin{array}{l}3.33 \\
* * *\end{array}$ \\
\hline $\begin{array}{l}\text { The government, rather than market forces, } \\
\text { should decide who gets to use Alberta } \\
\text { water. }\end{array}$ & .79 & & & $\begin{array}{l}3.54 \\
* * *\end{array}$ \\
\hline $\begin{array}{l}\text { If an irrigation district or municipality is not } \\
\text { using all of the water it has been allocated, } \\
\text { then the government should be able to take } \\
\text { that water for environmental purposes } \\
\text { without compensation. }\end{array}$ & .54 & & & $\begin{array}{l}3.20 \\
* * *\end{array}$ \\
\hline $\begin{array}{l}\text { The government should buy water from } \\
\text { current water licence holders, such as } \\
\text { irrigation districts, so that more water can } \\
\text { be left in the river for the environment. }\end{array}$ & & .73 & & $\begin{array}{l}3.16 \\
* * *\end{array}$ \\
\hline $\begin{array}{l}\text { Public funds should be used to improve } \\
\text { irrigation systems only if the water that is } \\
\text { saved is left in rivers. }\end{array}$ & & .67 & & $\begin{array}{l}3.43 \\
* * *\end{array}$ \\
\hline $\begin{array}{l}\text { Private individuals and groups should be } \\
\text { able to hold water licences for } \\
\text { environmental protection. }\end{array}$ & & .57 & & $\begin{array}{l}3.23 \\
* * *\end{array}$ \\
\hline $\begin{array}{l}\text { Public funds should be used to help larger } \\
\text { water users (irrigators, industries and } \\
\text { municipalities) to become more water } \\
\text { efficient. }\end{array}$ & & .47 & .42 & $\begin{array}{l}3.30 \\
* * *\end{array}$ \\
\hline $\begin{array}{l}\text { Minimum flows of water should be set for } \\
\text { all rivers, and only the water above those } \\
\text { minimum flows should be available for } \\
\text { economic purposes such as irrigation. }\end{array}$ & & .38 & & $\begin{array}{l}3.84 \\
* * *\end{array}$ \\
\hline $\begin{array}{l}\text { Water that is saved through improved water } \\
\text { use efficiency should be used to increase } \\
\text { economic activity. }\end{array}$ & & & .70 & $\begin{array}{l}3.10 \\
* * *\end{array}$ \\
\hline $\begin{array}{l}\text { All water licences, no matter when they } \\
\text { were issued or for what purpose, must be } \\
\text { honoured. }\end{array}$ & & & .68 & $\begin{array}{l}2.85 \\
* * *\end{array}$ \\
\hline Variance Explained & 18 & 17 & 13 & \\
\hline KMO & \multicolumn{3}{|c|}{0.675} & \\
\hline
\end{tabular}


water for the environment and is labelled 'Environmental Protection'. The third factor includes three policy statements which all reflect policies protecting the rights of existing licence holders and is labelled 'Pro Irrigation'. One policy statement has a factor loading of more than 0.4 on both factors two and three. This policy can be considered beneficial to both views as it does not specify how the saved water should be used.

Respondents are in overall agreement with nine out of ten statements and in disagreement with one (table 1). The highest level of support is for the policy of setting minimum flows for all rivers with a mean of 3.84 followed by leaving it to the government rather than market forces to allocate water with 3.54. The two 'Pro-irrigation' policies got the lowest mean score.

The pairwise ANOVA analysis indicates that there are no significant generational differences in the support for 'Strong Government' policies (Table 2). On the other hand, the level of support for 'Environmental Protection' policies differs significantly at the 0.01 level between all the generations except between 'older' and 'senior' where the difference is only significant at the 0.10 level. For 'Pro Irrigation' policies, the level of support also differs significantly between all generations except between 'youth' and 'senior'. The youngest and oldest generation seem to have similar level of support for policies designed to protect the rights of existing licence holders.

Table 2: $\quad$ Pairwise differences in policy preferences between generations.

\begin{tabular}{|l|c|c|c|}
\hline Difference between & \multicolumn{3}{|c|}{ Significant } \\
\cline { 2 - 4 } & $\begin{array}{c}\text { Government } \\
\text { Control }\end{array}$ & $\begin{array}{c}\text { Environment } \\
\text { Protection }\end{array}$ & Pro Irrigation \\
\hline Youth/Middle age & .778 & .000 & .008 \\
\hline Youth/Elder & .865 & .000 & .000 \\
\hline Youth/Senior & .678 & .000 & .327 \\
\hline Middle age/Elder & .878 & .000 & .028 \\
\hline Middle age/Senior & .501 & .000 & .001 \\
\hline Elder/Senior & .539 & .078 & .000 \\
\hline
\end{tabular}

However, ANOVA only tests for significant difference in variance; it does not prove causation between generation and policy preference and does not indicate which generation is more or less supportive. To test for causality, regression analyses were carried out for each policy orientation with the factor score for each respondent as the dependent variable and socio-demographic variables as independent variables. Among them a set of dummy variables indicating which generation the respondent belongs to, with 'middle aged' being the default reference generation. Hence, coefficients indicate level of support of a generation relative to 'middle aged' (Table 3 reports the coefficients for the generational variables only).

While the ANOVA analysis shows no generational difference in variance for 'Strong Government' policies; the regression analysis finds a significant positive relationship between 'senior' and 'Strong Government' policies at the 0.05 level, while the other coefficients are insignificant. However, their sign and magnitude 
suggest that the level of support is lowest among the youngest generation and support increases up through the generations, with seniors being significantly more likely to support these policies. All three generations are significant at the 0.01 level for 'Environment Protection' policies. The magnitude and sign of the coefficients prove that the support for policies designed to protect the environment decreases up through the four generations as the literature suggests. For 'Pro Irrigation' policies, two of the three generations are significant at the 0.05 and 0.01 level, respectively, while 'senior' is insignificant. The sign and magnitude of the coefficients suggest that support for policies designed to protect current licence holders decreases through the generations from 'youth' to 'elder/senior'.

Table 3: Regression coefficients generational variables for policy orientations.

\begin{tabular}{|l|l|l|c|}
\hline & $\begin{array}{c}\text { Government } \\
\text { Control }\end{array}$ & $\begin{array}{c}\text { Environment } \\
\text { Protection }\end{array}$ & Pro Irrigation \\
\hline Youth & -.002 & $.076^{* * *}$ & $.055^{* *}$ \\
\hline Elder & .016 & $-.106^{* * *}$ & $-.072^{* * *}$ \\
\hline Senior & $.062^{* *}$ & $-.074^{* * *}$ & -.010 \\
\hline Adjusted R Square & 0.158 & 0.275 & .258 \\
\hline Default variable: Middle aged, * sign $0.1, * *$ sign $0.05, * * *$ sign 0.01 level \\
\hline
\end{tabular}

\section{Conclusions: implications for the future of water sharing}

This study shows clear generational differences in policy preferences for water sharing. The future implications for water sharing in Alberta depend on whether these differences reflect a progression in policy preferences as a consequence of the aging process. If that is the case, then the overall support for water sharing policies will only change with a shift in the age profile of the overall population which is aging. This suggests that the overall support for environmental protection policies will be declining. If, however, the current younger generations will maintain their present view as they progress through the generations, then support for policies designed to protect the environment will increase in the future as will the support for policies designed to protect the interest of existing licence holders, which is a more surprising finding.

The study by Honnold [27] suggest that people hold on to their level of environmental concern as they age (though only based on a seven year longitudinal study) and that changes in people's environmental concern over time is more driven by "period effects", that is changes in the general political climate in the country. If these conclusions are correct, then the policy support among the voting public of Alberta will increase for both policies designed to protect the environment and policies designed to protect the interest of existing licence holders. This could suggest that the conflict between the two policy directions, which might be seen as having an opposite focus, might be 
increasing. It could, however, also result in a stronger willingness to accept compromises between consumptive and non-consumptive uses in the future which would be a favourable development. However, the second finding by Honnold et al., that change in the general political climate within a jurisdiction might play a significant role in policy preferences, might leave a less positive hope for the future.

\section{Acknowledgements}

This research received financial support from Alberta Innovates: Energy and Environment Solutions, the Canadian Water Network and the Social Sciences and Humanities Research Council, for that we are grateful. We also acknowledge the contribution made by three Master Students: Cameron Parrack, Martin Russenberger, Amber Zary and Matthew Hall who conducted the three surveys.

\section{References}

[1] Bjornlund H., Zuo, A., Wheeler S., Xu W., Edwards J. (2013): Policy preferences for water sharing in Alberta, Water Resources and Economics (1), 93-110.

[2] Bjornlund, H.; Parrack, C. and DeLoe, R. (in press): Segmenting residents of southern Alberta for improved understanding of policy preferences for water reallocation. Journal of Society and Natural Resources.

[3] Kelly, E., Schindler, D., Hodson, P., Short, J., Radmanovich, R., Nielsen, C. (2010): Oil sands development contributes elements toxic at low concentrations to the Athabasca River and its tributaries. Proceedings of the National Academy of Sciences 107(37), 16178-16183.

[4] AE, Alberta Environment (2003): South Saskatchewan River Basin water allocation. Author, Edmonton.

[5] AE, Alberta Environment (2003): Water for Life: Alberta's Strategy for Sustainability. Author, Edmonton.

[6] AE, Alberta Environment (2005): Background Information for Public Consultation on the South Saskatchewan River Basin's Draft Water Management Plan. Author, Edmonton.

[7] Byrne, J., Kienzle, S., Sauchyn, D. (2011): Prairie waters and climate change, in: Sauchyn, D., Diaz, H., Kulshreshtha, S. (Eds.), The New Normal: The Canadian Prairies in a Changing Climate. Canadian Plains Research Centre Press, Saskatchewan, Canada.

[8] AE, Alberta Environment (2003): Summary, SSRB Background Studies. Author, Edmonton.

[9] Kwasniak, A. (2010): International perspective: Water scarcity and aquatic sustainability: Beyond policy limitations, University of Denver Water Law Review, 13.

[10] Bjornlund, H. (2010): The Competition for Water: Striking a Balance among Social, Environmental and Economic Needs. Commentary No 302, C.D. Howe Institute, Toronto. 
[11] Rood, S. and Vandersteen, J. (2010): Relaxing the principle of prior appropriation: Stored water and sharing the shortage in Alberta, Canada, Water Resource Management, 24.

[12] Hadjigeorgalis, E. (2010): Incorporating the environment into the market: The case of water trusts and environmental water transfers in the western United States. In Bjornlund, $\mathrm{H}$. ed. Incentives and instruments for Sustainable Irrigation. WITPress, Southampton, UK.

[13] Lane-Miller C., Wheeler S., Bjornlund H., Connor J. (in press): Acquiring Water for the Environment: Lessons from Natural Resources Management, Journal of Environmental Policy and Planning.

[14] Wheeler, S., Garrick, D., Loch, A. and Bjornlund, H. (2013): Evaluating water market products to acquire water for the environment in Australia. Land Use Policy, 30, 427-436.

[15] Bjornlund, H.; Wheeler, S. and Rossini, P. (2013): Water Markets and Their Environmental, Social and Economic Impact in Australia. In Maestu, J. Ed. Water Trading and Global Water Scarcity: International Perspectives. Francis Taylor, UK, 68-93.

[16] Loch, A.; Bjornlund, H. and McIver, R. (2011): An institutional critique of differing allocation models to deliver environmental flows: Case studies of Queensland and Victoria in Australia. Environment and Planning C, 29, 745-760.

[17] NWC (2011): Water markets in Australia: a short history. National Water Commission, Canberra.

[18] Adamson, D. and Loch, A. (in press): Possible negative sustainability impacts from 'gold-plating' irrigation infrastructure. Accepted subject to minor review for publication in Agricultural Water Management.

[19] Hines, J. M., Hungerford, H. R. \& Tomera, A. N. 2010, Analysis and Synthesis of Research on Responsible Environmental Behavior: A MetaAnalysis, Journal of Environmental Education, 18(2), 1-8.

[20] Dunlap, R. and Heffernan, R. (1975): Outdoor Recreation and Environmental Concern: An Empirical Examination, Rural Sociology, 40(1), 18-30.

[21] Geisler, C., Martinson, O. \& Wilkening, E. (1977): Outdoor Recreation and Environmental Concern: A Restudy', Rural sociology, 42(2), 241249.

[22] Buttel, F. (1979): Age and Environmental Concern: A Multivariate Analysis, Youth and Society, 10, (3), 237-256.

[23] Kahn, M. and Matsusaka, J. (1997): Demand for environmental goods: evidence from voting patterns on California initiatives, Journal of Law and Economics 40 137-174.

[24] Huddart-Kennedy, E., Beckley, T., McFarlane, B. and Nadeau, S. (2009): Rural-Urban Differences in Environmental Concern in Canada, Rural Sociology, 74.

[25] Chapman, J. (2011): Who does what? The-pro-environmental behaviours of Australian workers, Centre for Work + Life, University of South Australia, Adelaide. 
[26] Whittaker, M., Segura, G. M. \& Bowler, S. 2005, 'Racial/Ethnic Group Attitudes toward Environmental Protection in California: Is "Environmentalism" still a White Phenomenon?', Political Research Quarterly, 58, 3, 435-447.

[27] Honnold, J. 1984, Age and Environmental Concern some specification of effects, Journal of Environmental Education, 16(1), 4-9. 